\title{
Reconsidering 'emotionally transmitted debt' in Zimbabwe and proposals for the reform of surety law based on English and South African experiences
}

\section{Introduction}

Since the dawn of history, commerce and, especially, the existence of credit have been linked with the need to indemnify the creditor or guarantee recovery of the borrowed amount (see Morgan 'History and economics of suretyship' 1927 Cornell L. Rev. 12 153; Russell Surety Bonds for Construction Contracts (2000) 9; Arnold 'The compensated surety’ 1926 Col. L. Rev. 26 171). As an instrument of minimising loss exposure, the contract of suretyship - both in the corporate and personal contexts - has gained increased importance in modern times (see generally Forsyth and Pretorius Caney's the Law of Suretyship in South Africa (2002); Gallagher The Law of Suretyship (2000)). Underlying its economic function is an acknowledgment that security is critical for the consummation of business activities; the availability of credit plays a facilitative role in boosting the economy through for instance, the creation of investment and employment (see Pretorius 'Unlimited suretyships' 2012 Journal of Contemporary Roman-Dutch Law 75 189; Madhuku 'Protection of the surety under Zimbabwean law'1997 Journal of African Law 41 1 68). In fact, ' $\ldots$ the provision of credit for trade and industry stimulates production and encourages enterprise as well as helping individuals and businesses over difficult economic times' (Cork 'Report of the Review Committee: Insolvency Law and Practice' (1982) 12 para 20. See also Gallagher The Law of Suretyship ((2000) 3-41).

How to cite: Kawadza 'Reconsidering 'emotionally transmitted debt' in Zimbabwe and proposals for the reform of surety law based on English and South African experiences' 2017 De Jure 194-201 http://dx.doi.org/10.17159/2225-7160/2017/v50n1a12 
Regrettably, despite the obvious beneficial outcomes, the growth of suretyship has also been linked to characteristic social and economic risks, especially to the surety. One such risk pertains to the emergence of the so-called 'emotionally transmitted debt' problem; a situation where one's decision to execute the deed of suretyship is swayed more by emotional ties or relational influences than by an awareness of the financial risks or the existence of economic benefits associated with the transaction. It is the recriminations and prejudicial consequences of such transactions that have led to the categorisation of some of these contracts as 'unfair suretyships' (see for instance Ciacchi and Weatherill (eds) Regulating Unfair Banking Practices in Europe: the Case of Personal Suretyships' (2010) 3; Kenny 'Standing surety in Europe: Common core or Tower of Babel? 2007 Modern Law Review 702 175). These are encapsulated roughly as 'suretyships entered into by consumers for the benefit of close relations or employers, whereby the surety has nothing to gain financially and faces the risk of lifelong indebtedness or severe financial loss, i.e. the loss of the matrimonial home' (Heine and Janal 'Suretyships and consumer protection in the European Union through the glasses of law and economics' in Ciacchi and Weatherill (eds) Regulating Unfair Banking Practices in Europe: The Case of Personal Suretyships' ((2010) 5; Pretorius 'Unlimited suretyships' (supra)). The consequence has been calls for the exercise of caution in cases where there is evidence of a relational connection. Primarily, this has been the case, due to the fear that consent to suretyship might be connected to, or involves, deferential trust. Such trust is said to be deferential:

in the sense that the trusting person will defer to the judgment of the trusted person. The deference may be total, or it may only be partial or situational. It is accompanied, in some cases, by elements of necessity, dependence or submission. In other cases there is no demonstrated vulnerability. But the trusted person knows that his or her judgment is being relied on in the circumstances (Flanigan 'The fiduciary obligation' 1989 Oxford Journal of Legal Studies 285, 286. See also Johnson v Buttress (1936) 56 CLR 113; Bigwood Exploitative Contracts (2003) 411).

It is, therefore, the potential for unfairness to arise which has justified the reconsideration, renegotiation and redefinition of the boundaries, and, indeed, the nature, form and principles that underpin the contract of suretyship in most European countries (see Ciacchi and Weatherill (eds) Regulating Unfair Banking Practices in Europe: the Case of Personal Suretyships' (supra) 3; Kenny 'Standing surety in Europe: Common core or Tower of Babel?' (supra)). It is the purpose of this note to propose, or, at the very least, to increase the likelihood of a paradigm shift in the current Zimbabwean approach to the law of suretyship in light of the recent case of FBC Bank Ltd $v$ Dunleth Enterprises (Pvt) Ltd, and to suggest alternatives based on exemplary approaches from a growing body of scholarship and jurisprudence. In particular, this note seeks to highlight England's approach to this issue. England and South Africa have been chosen for a simple reason, namely that they have managed to come up with strategies that are more effective aimed at addressing this subject. 
As such, South Africa and England present models that Zimbabwe could embrace with a view to crafting a regulatory approach that aligns suretyship with both economic and public policy principles.

\section{The Facts}

The principal debtor and the fifth defendant (hereafter 'the surety'), who were related, had executed an unlimited guarantee in favour of the plaintiff, FBC Bank Limited, a Zimbabwean commercial bank (hereafter 'FBC'). The surety accomplished this by availing her immovable property to FBC by way of a deed of hypothecation and guarantee. When the principal debtor defaulted, FBC instituted a claim against the defendants for the payment of USD 685 442.42, being the amount lent out, plus interest and costs associated with the subsequent litigation. Although she admitted that she signed the deed of suretyship, the surety argued that she was not liable for the whole amount borrowed by the principal debtor. In her submission, the surety argued that she had been approached by her relative (the principal debtor) who requested to use her property as security for the loan he intended to acquire from FBC. Further, she contended that he had assured her that the total loan amount would be USD 150000.

Although she never met any of FBC's officials, the surety nonetheless signed the deed of suretyship delivered to her by an employee of the principal debtor. She argued that said document had blank spaces, which were filled in after she had signed the form. She also averred that it was never brought to her attention that the principal debtor would make further borrowing on top of the USD 150000 which she had been assured was the limit of that facility. As such, she maintained that her liability only extended to that amount and not anything in excess. It was also her contention that by virtue of this limit, she was released from liability when the principal debtor made payments in excess of the USD 150 000, a claim which the court dismissed. She also stated that the principal debtor had guaranteed that he would repay the debt within three months which would culminate into her property being released.

To the extent that she was misled, the surety placed the blame squarely and solely at the doors of her relative, the principal debtor. In its judgment, the Zimbabwean High Court stated that by signing the deed of suretyship, she had assumed liability by operation of the caveat subscriptor doctrine. Judgment was accordingly given in favour of FBC.

\section{Evaluation and Proposals for Reform}

FBC Bank Ltd $v$ Dunleth Enterprises (Pvt) Ltd serves to establish two elements of the Zimbabwean approach to suretyship. Firstly, it proves that the concept of suretyship does not classify or differentiate such transactions in terms of 'unfairness' and, secondly, it manifests a regime that is indifferent as to whether the contract was a culmination, or not, of an underlying relational proximity between the principal debtor and 
the surety. As such, cases like FBC Bank Ltd v Dunleth Enterprises (Pvt) Ltd are not uncommon (see for instance Vito $v$ Vito [2008] ZWHHC 73; Madhuku 'Protection of the surety under Zimbabwean law'(supra)). In other jurisdictions, comparable cases to FBC Bank Ltd $v$ Dunleth Enterprises (Pvt) Ltd have prompted a rethink in the enforcement of contracts of suretyships. It is those jurisdictions' experiences and the subsequent academic discussions that emerged, as well as the persuasive judicial responses that were triggered, that reasonably engender expectancy for a rethink of the current Zimbabwean approach with the objective of making it responsive to the potential prejudices embedded in such tripartite transactions.

As alluded to above, other regimes demonstrate a growing consciousness of the possibility that, depending on the proximity of the relationship between the debtor and surety, the surety might be persuaded to conclude economically unfair contracts (see Devenney, Fox and Kenny 'Standing surety in England and Wales: The sphinx of procedural protection' 2008 Lloyd's Maritime and Commercial Law Quarterly 394). However, the settled law in Zimbabwe - as exemplified by FBC Bank Ltd $v$ Dunleth Enterprises (Pvt) Ltd - has not given any attention to the concept of 'unfair suretyship'. Neither does it seek to investigate the clarity or the contractual terms' fairness. This is lamentable, especially considering that

[t]he printed documentation used by banks is of such length, complexity and obscurity that is unlikely to be read let alone understood by private guarantors who lack training or appropriate business experience. They are treated by banks as contracts of adhesion discouraging any attempt to modify any of their terms. They are often unduly favourable to the bank and excessively onerous to the surety' (Lord Woodhouse in Royal Bank of Scotland plc $v$ Etridge (No 2) [2001] UKHL 44 at 111)(My emphasis).

As such, the Zimbabwean position is still captive to general legal doctrine and rigid common law principles which hold that, in the absence of duress or undue influence (see e.g. Muza $v$ Agricultural Bank of Zimbabwe Ltd. (22/02) ((22/02)) [2004] ZWSC 138 (05 October 2004); Johnson v AFC 1995 (1) ZLR 65), the surety is deemed to have acted consistently with her liberty, as long as it can be shown that her will was not 'subordinated', 'surrendered', 'dominated', 'controlled', 'subverted' or 'overcome' (Bigwood Exploitative Contracts (2003) 374; Madhuku 'Protection of the surety under Zimbabwean law' (supra)).

What needs to be understood is the fact that "[i]t is not a matter of mental power, forcefulness, or weakness that is at issue, or mere forcefulness versus weakness of mind' (Bigwood Exploitative Contracts (supra) 375). Therefore, the Zimbabwean approach needs to take cognisance of facts besides domination and control as factors indicating lack of consent,

[t]here may have been misplaced trust or reliance, but the victim still acts 'intentionally', perhaps even acceding to the transaction euphorically ... what 
the ascendant party does in the undue influence context ... is wrongfully make the option put to the subservient party (ie, of entering into the transaction in question) appear to be a reasonable thing to do in the circumstances (Bigwood 'Undue influence: 'Impaired consent' or 'Wicked exploitation'?' 1996 Oxford J Legal Stud 16503 p 511. See also Birks and Chin 'On the nature of undue influence' in Beatson and Friedmann (ed), Good Faith and Fault in Commercial Law (1995) 76).

In a contextual exemplification of said misplaced trust or reliance, the court in casu indicated that 'the fifth defendant [surety] stated that she was assured by the second defendant (the debtor) that he would repay the loan to the plaintiff within three months and that her security was required just for that period [my emphasis]', an averment which the principal debtor refuted in court. The court further noted that, in the case of FBC, neither the bank, nor its employees assured the surety of a limit to her liability in terms of the suretyship. Thus while her transactional assent was not as a result of force, it nonetheless may have been wrongful in that it might have been a culmination of undue influence and, thus, an exploitative use of special trust. Clearly, in the absence of any direct communication between the creditor and surety, it is reasonable to speculate that there might have been an error in judgment, arising out informational asymmetry created by the principal debtor's influence.

While correctly noting that the contract of suretyship was between the FBC and the surety, the court nevertheless did not closely examine this risk, and, instead, relied on the caveat subcriptor doctrine to rule in favour of the bank. Furthermore, having noted that the surety and principal debtor were related, the High Court nonetheless did not concern itself with the factors that gave rise to the surety's assent.

It is, therefore, clear that there is currently no tool at the Zimbabwean court's disposal to judge the suretyship contract on the basis of any influence that the principal debtor might have had on the surety. It is on this basis that Zhou J disregarded the fact that

any close relationship implies a certain amount of influence of one person upon the other party. In asking a relation to act as surety, the principal debtor may be exerting undue influence, either in terms of excessive pressure, emotional blackmail, or by abusing the trust and confidence the prospective surety has reposed in the principal debtor ... Second, even if the prospective surety is fully informed about the risks of the transaction and the principal debtor does not overbear his or her will, the desire to assist the close relation in his or her ventures may lead this person to act 'irrationally' in assuming the risk ...' (Heine and Janal 'Suretyship and consumer protection in the EU' in Ciacchi and Weatherill Regulating Unfair Banking Practice in Europe. The Case of Personal Suretyships (supra) 13.

Perhaps it would be helpful if a rule could be developed to place the onus on the creditor to ensure that the suretyship is fair. 
Understandably, ascertaining the absence of fair dealing affecting transactional consent is by no means an easy feat to achieve (JT Pretorius 'Unlimited suretyships' (supra) 195). The practical hindrances stem from the reality that ' $[t]$ he limits of persuasion are in general more difficult to discern than the limits of coercion ... since the latter are generally linked to a background scheme of rights...' (Bigwood Exploitative Contracts (supra) 374. Thus, 'influence' is an abstract concept, which encapsulates not only coercion but also any form of 'fiduciary influence', which may be manifested in inter alia, reckless and misleading statements. The underlying factor is that

regardless of how the influence is exercised ... (for example, pressure, flattery, advice, argument, pleading, intercession, non-disclosure, and the like), the fact that such influence is successfully employed at all ... affords a sufficient exculpatory reason (again, all things being equal) to reverse the impugned transaction ...' (Bigwood Exploitative Contracts (supra) 380).

In view of the challenge that the surety faces to exculpate themselves, it has been argued that on public policy grounds, the onus should be on the creditor to show firstly, that the suretyship was the culmination of an independent act and further, that the surety exercised free judgement on the basis of full information that was the debtor was privy to. More specifically, the presumption should be whether at the time of transactional assent the parties were in a special relationship that gave the creditor some capacity to influence or control the decision making of the surety (Barclays Bank v O'Brien [1994] 1 AC 180; Bigwood Exploitative Contracts (supra) 425).

It has been suggested that this could be accomplished, inter alia, by doing away with the terminological rigidity - especially as it is impossible to capture the qualities of a special relationship in a precise label or phrase. This is one area where section 64 of the South African National Credit Act (Act No. 34 of 2005) may be commended. It requires that documents to be drafted in plain language that a person of average literacy skills would understand. Unfortunately, Zimbabwe is yet to enshrine similar protection.

Needless to say, that the proximity should be contextually and loosely interpreted to include trust and confidence (Etridge (supra) 1030, para 11 per Lord Nicholls; Bigwood Exploitative Contracts (supra) 427). Furthermore, although closeness giving rise to relational influence has customarily been branded as covering cases such as parent-child and guardian-ward (e.g. Hatch v Hatch (1804) 9 Ves Jun 292; Bullock v Lloyds Bank [1955] I Ch 317), medical adviser-patient (Mitchell v Homfrey [1 881] 8 QB 587; Dent $v$ Bennet (1839) 4 My \& Cr 269; 41 ER 105), it is argued that these should not be the only overriding associations. In fact

[i]nferences should flow from a careful examination of the particular facts rather than from a formal relationship per se, although the existence of such a relationship will of course be a vital fact from which inferences of special influence may quite readily be drawn (Bigwood 434). 
This laudable approach seems to be premised on the perceived exigencies and practical necessity to reconcile the social and economic implications arising from suretyships. That approach is, therefore, an intersection of commerce and public policy and at the heart of the issue is a need to ensure that certain precautionary steps are implemented. More specifically it would be helpful if Zimbabwean law could require that any creditor who fails to put in place necessary safeguards to satisfy himself that the surety has been sufficiently protected from the potential prejudice arising from her connection with the principal debtor in the surety transaction, and who fails to ensure that the surety has understood the nature and effect of the proposed surety contract, would himself be liable for transactional neglect. There is merit in such proposals. For instance, the inequality inherent in contracts involving financial institutions in particular has led some to observe that,

It is an economic reality today that the terms of the vast majority of deeds of suretyship are dictated to sureties by large financial institutions. These deeds of suretyship are drafted with all the skilled legal advice available and, inevitably, favour the creditor in almost every aspect. In light of the inherent potential inequities and the devastating consequences that may flow from standing surety for somebody else's debt, it is hardly surprising to find that throughout the ages there have been many attempts to lighten the burden of the surety' (JT Pretorius 'Unlimited suretyships' (supra) 196. See also for instance Davids $v$ ABSA Bank Bpk 2005 (3) SA 361)

Furthermore, there is need to devise mechanisms that might minimise the manifest prejudicial contracts arising from relational factors or influence. One way that Zimbabwe could accomplish this is by way of judicial policy that built around vigilance. Similarly, due diligence on the part of the creditor must include, for instance, a condition that the individual intending to stand as surety be required to attend a meeting with the creditor where the nature and consequences of the contract can be explained. In addition, the potential surety must be required to nominate a legal representative for the purpose of the transaction. That legal representative must provide written confirmation proving that the intricacies of the transaction were explained to the surety. Likewise, a rebuttable presumption of causative and inherent undue influence in suretyships that involve relational proximity in non-commercial suretyships could help.

\section{Conclusion}

FBC Bank Ltd $v$ Dunleth Enterprises (Pvt) Ltd is salutary because it shines the spotlight on the current approach to suretyships in Zimbabwe. Moreover, it provides a crucial platform upon which the prevailing regime can be analysed. Having done do so, this note argues that $F B C$ Bank Ltd $v$ Dunleth Enterprises (Pvt) Ltd translates to a missed opportunity to grapple with the perturbing issue of 'emotionally transmitted debt' in Zimbabwe. 
This is not to say that the notion of suretyship in Zimbabwe should be revisited to rescue people from their poor judgment and recklessness, among other follies. Rather, this note entreats for an environment which acknowledges not only the onerous and risky nature of the current law, but also the recognition of the existence of 'unfair suretyships' arising from the possible relational influences in the consummation of such onerous transactions in Zimbabwe. This note, therefore, seeks to provide conceptual proposals for a more equitable approach to the law governing suretyship in Zimbabwe.

H KAWADZA

Wits University Law School 